\title{
PENGUJIAN VIGOR BENIH KEDELAI VARIETAS GROBOGAN HASIL PEMUPUKAN NPK MAJEMUK PADA UMUR SIMPAN DUA BULAN
}

\author{
Parmitha Shari, Yayuk Nurmiaty \& Niar Nurmauli \\ Jurusan Agroteknologi, Fakultas Pertanian Universitas Lampung \\ Jl. Prof. Soemantri Brodjonegoro, No.1, Bandar Lampung 35145 \\ E-mail: parmitha.shari@yahoo.com
}

\begin{abstract}
ABSTRAK
Benih merupakan salah satu bahan usaha tani yang mempengaruhi hasil. Penggunaan benih bermutu yang memiliki vigor tinggi merupakan salah satu faktor yang dapat menghasilkan panen tanaman yang tinggi. Dosis pupuk NPK majemuk selama periode pembangunan benih diduga mempengaruhi vigor suatu benih. Penelitian ini bertujuan mengetahui perbedaan vigor benih kedelai Varietas Grobogan yang berasal dari dosis pemupukan NPK majemuk berbeda. Penelitian dilaksanakan di Laboratorium Pemuliaan dan Teknologi Benih Fakultas Pertanian Universitas Lampung, Bandar Lampung dari bulan April hingga Mei 2012. Percobaan dirancang menggunakan rancangan kelompok teracak sempurna (RKTS) yang diulang tiga kali. Rancangan perlakuan adalah tunggal terstruktur terdiri dari lima taraf dosis pupuk NPK majemuk $\left(100 \mathrm{~kg} \mathrm{ha}^{-1}, 150 \mathrm{~kg} \mathrm{ha}^{-1}, 200\right.$ $\mathrm{kg} \mathrm{ha}^{-1}, 250 \mathrm{~kg} \mathrm{ha}^{-1}$, dan $300 \mathrm{~kg} \mathrm{ha}^{-1}$ ). Homogenitas ragam diuji dengan Uji Barlett dan aditivitas data diuji dengan Uji Tukey. Bila asumsi analisis ragam terpenuhi, maka data dianalisis ragam; rata-rata nilai pengaruh perlakuan diuji dengan Uji Ortogonal Polinomial pada taraf 0,05. Hasil penelitian menunjukkan bahwa benih kedelai Varietas Grobogan yang berasal dari pemupukan NPK majemuk yang ditingkatkan dosisnya sampai dengan $300 \mathrm{~kg} \mathrm{ha}^{-1}$ menghasilkan perbedaan vigor benih secara kuadratik berdasarkan variabel bobot kering kecambah. Pada dosis pupuk 178,95 $\mathrm{kg} \mathrm{ha}^{-1}$ menghasilkan bobot kering kecambah maksimum yaitu $0,08 \mathrm{~g} /$ kecambah sedangkan panjang akar dan panjang plumula meningkat secara linier seiring dengan peningkatan dosis pupuk. Variabel kecepatan perkecambahan, kecambah normal yang tumbuh, nilai daya hantar listrik, dan panjang hipokotil tidak menunjukkan perbedaan meskipun dosis pemupukan ditingkatkan.
\end{abstract}

Kata kunci : Grobogan, kedelai, pupuk NPK majemuk, vigor

\section{PENDAHULUAN}

Benih merupakan salah satu masukan usaha tani yang mempengaruhi tingkat hasil. Penggunaan benih bermutu tinggi dalam budidaya akan menghasilkan panen tanaman yang tinggi pula. Benih bermutu memiliki vigor tinggi yang akan memberikan respons yang positif terhadap input agronomi seperti pupuk sehingga mampu mencapai produksi maksimum. Vigor benih dapat diketahui dengan melakukan pengujian vigor. Variabel yang diukur pada pengujian vigor antara lain kecambah normal, nilai daya hantar listrik, variabel pertumbuhan, dan bobot kering. Menurut Ilyas (2010), lot benih yang viabilitasnya lebih tinggi akan mampu menghasilkan bobot kering kecambah lebih besar.

Menurut Sadjad (1993), viabilitas benih mencakup vigor dan daya berkecambah benih. Viabilitas adalah daya hidup benih yang ditunjukkan oleh gejala pertumbuhan dan atau gejala metabolisme. Vigor benih berkembang dengan pola menyerupai perkembangan viabilitas. Bila vigor menurun, maka viabilitas juga ikut menurun. Vigor benih merupakan sifat-sifat benih yang menentukan potensi benih untuk tumbuh cepat, seragam, dan berkembang menjadi kecambah normal pada berbagai kondisi lingkungan (AOSA, 1983).

Benih bervigor tinggi merupakan resultan dari faktor innate (genetik) dan induced (lingkungan). Mugnisjah dan Setiawan (2004) menyatakan bahwa pertanaman untuk memproduksi benih harus tumbuh dalam lingkungan optimum. Salah satu faktor lingkungan tersebut adalah ketersediaan unsur hara yang tercukupi. Periode satu pada konsep viabilitas benih SteinbauerSadjad merupakan periode pembangunan benih atau pembentukan benih. Teknik pemupukan yang baik pada periode I, akan menghasilkan vigor awal yang tinggi. Menurut Sadjad (1993), vigor awal adalah status vigor benih pada saat masak fisiologis. Vigor awal mempengaruhi dalam penyimpanan benih. Semakin tinggi vigor awal yang dibawa benih maka semakin lama benih dapat disimpan. Pemupukan yang mendukung pertumbuhan dan hasil benih, tergantung dari cara pemupukan, dosis pupuk yang tepat, dan waktu pemupukan.

Pupuk NPK majemuk mengandung unsur nitrogen, fosfor, dan kalium yang berperan dalam pembentukan protein yang menghasilkan vigor (Lowe 
et al., 1972), cadangan energi untuk perkecambahan (Bewley dan Black, 1986), bobot benih, dan menurunkan asam lemak bebas dalam benih sehingga daya simpan benih akan lebih lama.

Hasil penelitian Rusdi (2008) menyatakan bahwa benih kedelai yang diberi pupuk NPK susulan sampai dosis $100 \mathrm{~kg} \mathrm{ha}^{-1}$ menghasilkan vigor awal yang tinggi berdasarkan variabel nilai daya hantar listrik. Hasil penelitian Avintari (2008) menyatakan bahwa dosis pupuk NPK majemuk berpengaruh pada vigor buncis secara linier yaitu setiap peningkatan $1 \mathrm{~kg} \mathrm{ha}^{-1}$ pupuk NPK majemuk akan meningkatkan bobot kering kecambah sebesar $0,0017 \mathrm{~g}$.

Pemupukan dengan dosis yang berbeda tentunya akan menghasilkan tanggapan yang berbeda pula oleh tanaman baik secara kuantitas maupun kualitas (mutu benih). Semakin tinggi dosis pupuk yang diberikan maka ketersediaannya dalam tanah akan semakin besar dan serapan tanaman akan semakin meningkat. Namun, tanggapan tanaman terhadap penambahan pupuk tidak selalu positif, tanaman akan menanggapi positif bila dosis pupuk belum mencapai optimum. Dosis optimum dalam pemupukan merupakan salah satu upaya untuk menghasilkan benih bermutu atau bervigor yang tinggi.

Tujuan penelitian ini adalah mengetahui ada tidaknya perbedaan vigor pada benih kedelai Varietas Grobogan yang berasal dari pemupukan NPK majemuk berbeda setelah benih

disimpan dua bulan.

\section{BAHAN DAN METODE}

Penelitian ini dilaksanakan di Laboratorium Pemuliaan dan Teknologi Benih Universitas Lampung pada bulan April 2012 sampai dengan Mei 2012. Alat yang digunakan adalah ember, alat tulis, germinator, gelas ukur, konduktometer WTW Tetracon 325, glassjar, tissue, oven, alat pembagi tepat, timbangan, dan nampan. Bahan yang digunakan adalah kertas koran, air, karet gelang, benih kedelai Varietas Grobogan yang berasal dari pemupukan NPK majemuk $100 \mathrm{~kg} \mathrm{ha}^{-1} ; 150 \mathrm{~kg} \mathrm{ha}^{-}$ ${ }^{1} ; 200 \mathrm{~kg} \mathrm{ha}^{-1} ; 250 \mathrm{~kg} \mathrm{ha}^{-1}$; dan $300 \mathrm{~kg} \mathrm{ha}^{-1}$ yang telah disimpan 2 bulan, kertas label, air bebas ion, dan larutan $\mathrm{KCl} 0,01 \mathrm{M}$.

Percobaan dirancang menggunakan rancangan kelompok teracak sempurna (RKTS) yang diulang tiga kali. Rancangan perlakuan adalah tunggal terstruktur terdiri dari lima taraf dosis pupuk NPK majemuk. Homogenitas ragam diuji dengan uji Barlett dan aditivitas data diuji dengan uji Tukey. Bila asumsi analisis ragam terpenuhi, maka rata-rata nilai pengaruh perlakuan diuji dengan uji Ortogonal Polinomial pada taraf 0,05.
Persiapan benih uji diambil dari petak panen penelitian Panji Setyo Arizka yang berukuran $1 \mathrm{~m} \times 2 \mathrm{~m}$ dari masing-masing perlakuan peningkatan taraf dosis pupuk NPK majemuk dalam 2 kali pemberian. Benih kedelai dipanen pada sekitar bulan Februari 2012 (14 MST). Benih kedelai yang telah bersih dimasukkan ke lima kantong plastik sesuai dengan perlakuan taraf dosis pupuk yaitu $100 \mathrm{~kg} \mathrm{ha}^{-1}, 150 \mathrm{~kg} \mathrm{ha}^{-1}, 200 \mathrm{~kg} \mathrm{ha}^{-1}, 250 \mathrm{~kg}$ $\mathrm{ha}^{-1}$, dan $300 \mathrm{~kg} \mathrm{ha}^{-1}$. Selanjutnya benih kedelai dikeringkan secara alami di bawah sinar matahari. Kantong-kantong berisi benih kedelai yang telah dikeringkan kemudian disimpan pada alat penyimpanan benih. Contoh kerja benih diambil sekitar 70-80 gram menggunakan alat pembagi tepat.

Media perkecambahan menggunakan kertas koran. Kertas koran berlapis tiga digunakan sebagai lembar alas tanam dan kertas koran berlapis dua digunakan sebagai lembar penutup tanam. Lapisan kertas koran direndam dalam air hingga basah semua bagiannya, lalu ditiriskan hingga cukup lembab.

Pengujian kecepatan dan keserempakan perkecambahan benih dilakukan dengan menanam benih uji di atas kertas koran berlapis tiga sebanyak 25 butir benih dengan susunan yang teratur dan rapih. Dua lembar kertas koran lembab lagi digunakan untuk menutup benih yang telah tersusun rapi. Kertas koran yang telah disusun benih digulung. Setiap perlakuan diulang tiga kali, setiap ulangan terdapat 4 gulungan benih berisi 25 butir. Label tanda uji disiapkan dan ditulis jenis benih dan tanggal pengujian. Gulungan kertas koran yang telah disusun benih diletakkan posisi berdiri pada rak APB 73-2B. Pengamatan kecepatan perkecambahan dilakukan pada hari ke-2 sampai ke-5 yaitu menghitung kecambah normal yang tumbuh, pengamatan kecambah yang tumbuh dilakukan pada hari ke 4 dengan menghitung kecambah normal. Kecambah kemudian dikeringkan untuk mendapatkan bobot kering kecambah.

Pengujian uji daya hantar listrik (uji DHL) dilakukan dengan cara berikut. Sebanyak 10 butir benih kedelai ditimbang. Benih kedelai tiap ulangan dimasukkan ke dalam glassjar dan ditambahkan $50 \mathrm{ml}$ air bebas ion. Blanko dibuat dengan hanya diisi air pada glassjar. Glassjar ditutup untuk mencegah kontaminasi dan diletakkan pada suhu konstan $20 \pm 2$ p C selama 24 jam. Menyiapkan konduktometer yang telah dibersihkan dan dilakukan pemanasan secara manual. Air bebas ion sebanyak 400-600 ml disiapkan dalam glassjar untuk membilas dip cell pada setiap pengukuran. Kalibrasi alat selalu dilakukan menggunakan larutan $\mathrm{KCl} 0,01 \mathrm{M}$ (pembacaan larutan ini harus menunjukkan nilai antara $1273-1278 \mu \mathrm{S} / \mathrm{cm}$ ). Glassjar berisi benih yang telah direndam selama 24 jam, diguncang selama 10-15 detik 
untuk memastikan pencampuran yang merata dengan larutan rendaman. Air rendaman benih dipindahkan kedalam glassjar lain yang bersih dengan menuangkan benih dan air menggunakan saringan. Dip cell dimasukkan ke dalam air rendaman serta ukur/baca nilai konduktivitasnya.

Variabel pengamatan pada penelitian ini yaitu persentase kecepatan perkecambahan, nilai kecambah normal, nilai daya hantar listrik, panjang akar, panjang hipokotil, panjang plumula, dan bobot kering kecambah.

\section{HASIL DAN PEMBAHASAN}

Hasil penelitian menunjukkan bahwa benih yang berasal dari pemupukan NPK majemuk berpengaruh pada vigor benih kedelai Varietas Grobogan berdasarkan variabel panjang akar kecambah, panjang plumula, dan bobot kering kecambah tetapi tidak berpengaruh pada kecepatan dan keserempakan perkecambahan, uji DHL, dan panjang hipokotil (Tabel 1).

Benih yang berasal dari pemupukan NPK majemuk menghasilkan nilai kecepatan perkecambahan rata-rata sebesar $12,87 \%$, kecambah normal rata-rata sebesar $60,73 \%$, nilai daya hantar listrik rata-rata 1,82 $\mu \mathrm{mhos} / \mathrm{cm} / \mathrm{g}$, dan panjang hipokotil rata-rata sebesar 2,30 $\mathrm{cm}$. Pada variabel panjang akar dan panjang plumula, dosis pupuk NPK majemuk berpengaruh secara linier (Gambar 1 dan 2). Setiap peningkatan $1 \mathrm{~kg} \mathrm{ha}^{-1}$ pupuk NPK majemuk akan meningkatkan panjang akar sebesar $0,001 \mathrm{~cm}$ dan panjang plumula sebesar 0,00031 $\mathrm{cm}$. Pada variabel bobot kering kecambah, dosis pupuk NPK majemuk berpengaruh secara kuadratik yang menunjukkan nilai optimum sebesar $0,08 \mathrm{~g}$ pada dosis $178,95 \mathrm{~kg} \mathrm{ha}^{-1}$ (Gambar 3).

Benih kedelai Varietas Grobogan yang berasal dari pemupukan NPK majemuk berpengaruh pada vigor benih. Hasil penelitian menunjukkan bahwa benih yang berasal dari pemupukan NPK majemuk sampai dosis $300 \mathrm{~kg} \mathrm{~h}^{-1}$ memberikan pengaruh pada vigor benih kedelai Varietas Grobogan berdasarkan variabel panjang akar kecambah, panjang plumula, dan bobot kering kecambah tetapi tidak berpengaruh pada kecepatan perkecambahan, kecambah normal yang tumbuh, nilai DHL, dan panjang hipokotil.

Tabel 1. Hasil pengujian vigor benih kedelai Varietas Grobogan umur simpan dua bulan yang berasal dari pemupukan NPK majemuk

\begin{tabular}{lccccccc}
\hline Regresi & $\begin{array}{c}\text { Kecepatan } \\
\text { perkecambahan }\end{array}$ & $\begin{array}{c}\text { Kecambah } \\
\text { normal }\end{array}$ & $\begin{array}{c}\text { Nilai daya } \\
\text { hantar } \\
\text { listrik }\end{array}$ & $\begin{array}{c}\text { Panjang } \\
\text { akar }\end{array}$ & $\begin{array}{c}\text { Panjang } \\
\text { hipokotil }\end{array}$ & $\begin{array}{c}\text { Panjang } \\
\text { plumula }\end{array}$ & $\begin{array}{c}\text { Bobot } \\
\text { kering } \\
\text { kecambah }\end{array}$ \\
\hline Linear & tn & tn & tn & $*$ & tn & $*$ & $*$ \\
Kuadratik & tn & tn & tn & tn & tn & tn & $*$ \\
\hline
\end{tabular}

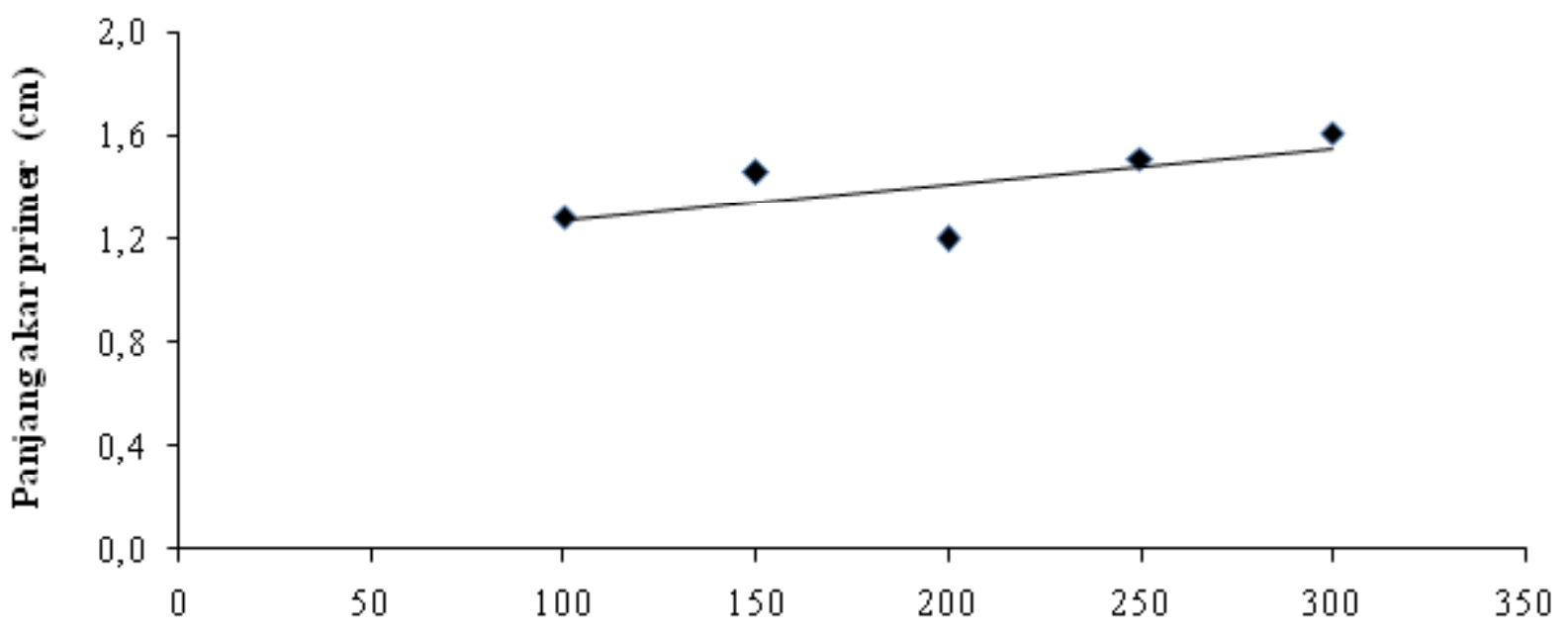

Dosis pupuk NPK majemuk (kg ha-1)

Gambar 1. Hubungan antara dosis pupuk NPK majemuk dan panjang akar primer kecambah. $y=0,001 \mathrm{x}+1,123$; $\mathrm{r}=0,66^{*}$ 


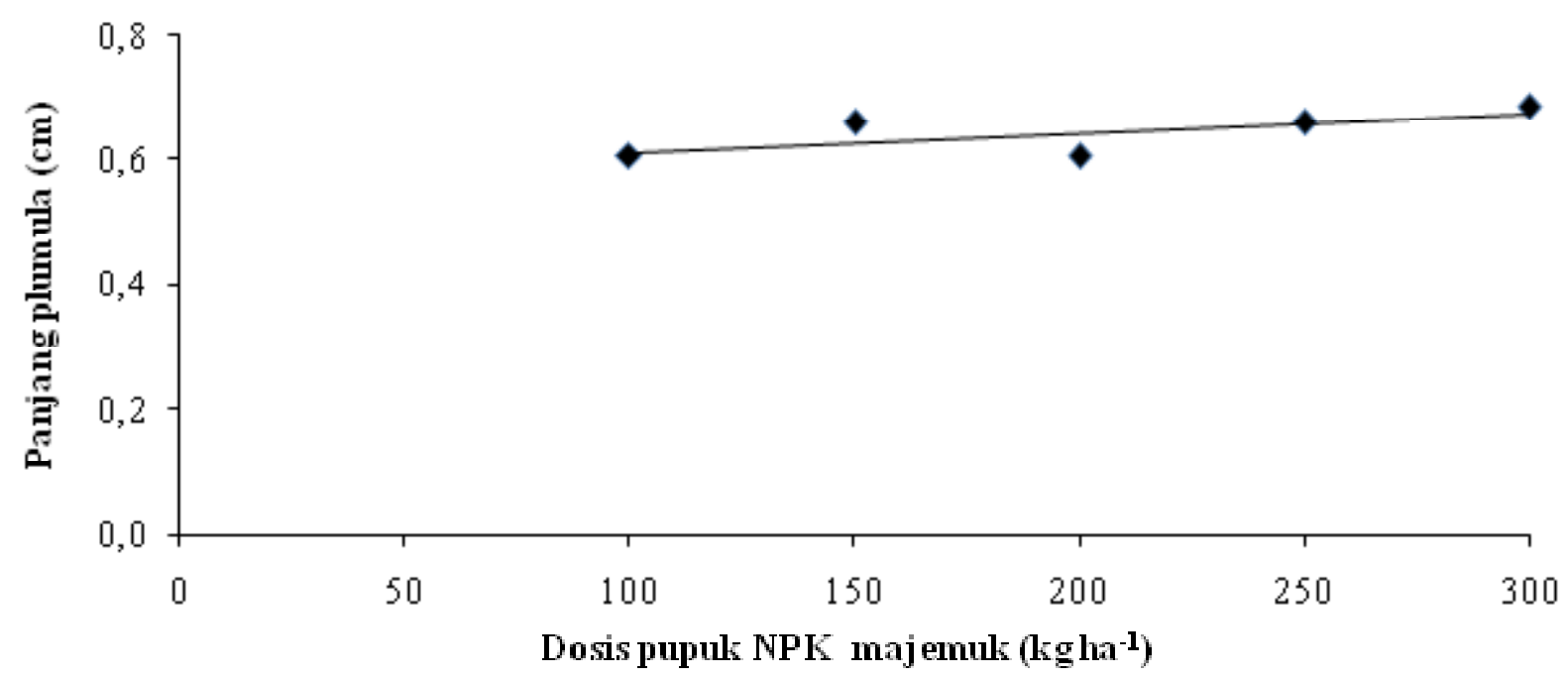

Gambar 2. Hubungan antara dosis pupuk NPK majemuk dan panjang plumula kecambah. $y=0,00031 \mathrm{x}+0,58$; $\mathrm{r}=0,70^{*}$

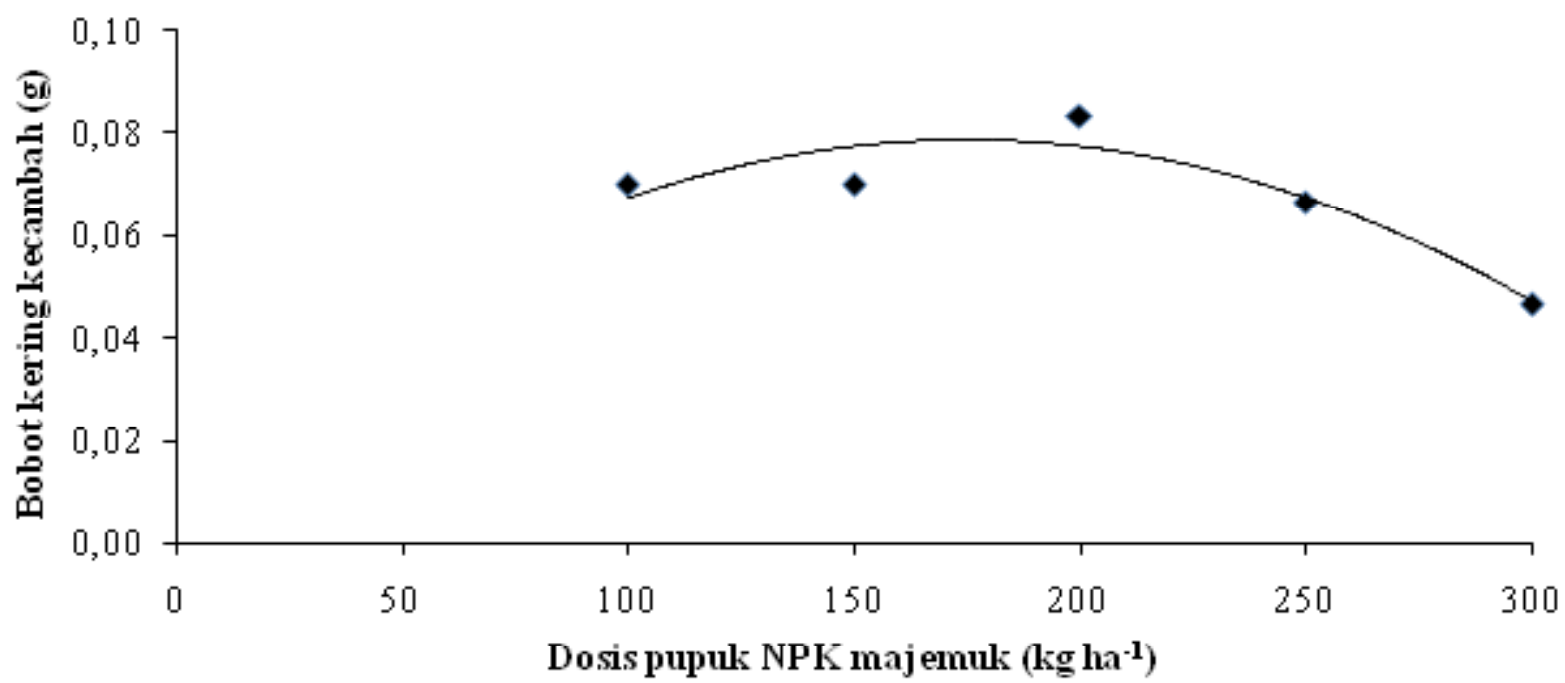

Gambar 3. Hubungan antara dosis pupuk NPK majemuk dan bobot kering kecambah. $y=-0,0000019 x^{2}+0,00068 x$ $+0,017 ; \mathrm{R}^{2}=0,801^{*}$

Hasil penelitian menunjukkan bahwa dosis pupuk NPK majemuk berpengaruh secara kuadratik pada bobot kering kecambah yaitu maksimum 0,08 g pada dosis $178,95 \mathrm{~kg} \mathrm{ha}^{-1}$. Variabel lain seperti kecepatan perkecambahan dan kecambah normal yang tumbuh menunjukkan hasil yang tidak berbeda. Meskipun kecepatan berkecambah dan kecambah normal yang berasal dari uji keserempakan tidak menunjukkan perbedaan vigor tetapi setelah kecambah tersebut dikeringkan ternyata menunjukkan hasil vigor yang berbeda jika pemupukan NPK ditingkatkan sampai 300 $\mathrm{kg} \mathrm{h}^{-1}$. Menurut Ilyas (2010), lot benih yang viabilitasnya lebih tinggi akan mampu menghasilkan bobot kering kecambah lebih besar. Hasil penelitian ini yang menunjukkan adanya pengaruh dosis pupuk NPK majemuk pada vigor benih berdasarkan variabel bobot kering benih sejalan dengan hasil penelitian Avintari (2008) bahwa dosis pemupukan NPK mempengaruhi vigor benih berdasarkan bobot kering kecambah buncis.

Pengukuran bobot kering kecambah merupakan tolok ukur yang lebih kuantitatif dan obyektif. Bobot kering kecambah normal menggambarkan kemampuan benih dalam memanfaatkan cadangan makanan untuk tumbuh menjadi kecambah normal. Cadangan makanan di dalam benih dipengaruhi oleh faktor lingkungan terutama ketersediaan hara. Hal ini sesuai dengan pendapat Sadjad (1993) yang menyatakan bahwa salah satu faktor yang mempengaruhi viabilitas benih selama periode I adalah faktor induced yaitu kondisi lingkungan pertanaman yang meliputi ketersediaan hara, air, dan 
cahaya. Peningkatan bobot kering kecambah sebagai tanggapan terhadap peningkatan dosis pupuk NPK majemuk.

Pada saat proses perkecambahan, terjadi perombakan asimilat atau cadangan makanan oleh enzim-enzim serta naiknya tingkat respirasi benih (Sutopo, 2002). Peningkatan laju respirasi akan mengaktifkan enzim-enzim yang terdapat dalam benih. enzim amilase merombak pati menjadi gula (glukosa, fruktosa, dan sukrosa), glukan fosfatase merombak senyawa yang mengandung $\mathrm{P}$, lipase yang merombak lemak menjadi gliserol dan asam lemak, dan protease yang merombak protein menjadi asam amino. Saat terjadi respirasi juga terbentuk air dan $\mathrm{CO}_{2}$. Pada hasil penelitian, bobot kering kecambah normal turun setelah melewati dosis optimum (Gambar 3), hal ini diduga berhubungan kadar air yang tinggi dari hasil respirasi sehingga saat kecambah dikeringkan, bobot kering kecambah normal yang berasal dari pemupukan NPK dosis tinggi akan semakin berkurang akibat kehilangan air.

Asimilasi dari bahan-bahan yang telah diuraikan saat proses perkecambahan akan menghasilkan energi bagi pembentukan komponen dan pertumbuhan sel-sel baru di daerah meristematik. Penambahan ukuran atau volume serta jumlah sel disebut dengan pertumbuhan. Variabel panjang akar dan panjang plumula merupakan gejala pertumbuhan dan perkembangan kecambah. Hasil penelitian menunjukkan bahwa variabel panjang akar dan panjang plumula cenderung linier seiring dengan penambahan dosis pupuk NPK majemuk. Panjang akar dan panjang plumula akan terus memanjang seiring pertambahan jumlah sel dan pemanjangan sel sehingga belum menunjukkan nilai maksimum hingga dosis 300 $\mathrm{kg} \mathrm{ha}^{-1}$. Penambahan volume sel akan menyebabkan bertambahnya bobot kecambah dan pemanjangan sel akan menyebabkan bertambahnya panjang kecambah. Meskipun panjang hipokotil tidak menunjukkan perbedaan vigor tetapi berpengaruh pada bobot kecambah dikarenakan perbedaan volume sel pada kecambah.

Hasil penelitian menunjukkan bahwa dosis optimum pupuk NPK majemuk dalam produksi benih kedelai yang bervigor tinggi hampir sesuai dengan dosis rekomendasi pemerintah. Dosis pupuk NPK majemuk rekomendasi pemerintah pada tahun 2009 untuk komoditas kedelai sebesar $200 \mathrm{~kg} \mathrm{ha}^{-1}$. Hasil penelitian menunjukkan bahwa dosis optimum pupuk NPK majemuk yang menghasilkan vigor benih tertinggi berdasarkan bobot kering kecambah sebesar 178,95 kg $\mathrm{ha}^{-1}$.
Pupuk NPK majemuk mengandung unsur nitrogen, fosfor, dan kalium yang berperan dalam pembentukan kualitas benih (mutu benih). Menurut Mugnisjah dan Nakamura (1984), nitrogen berperan dalam pembentukan protein. Kadar N yang cukup dalam benih menyebabkan benih lebih tahan disimpan, Unsur P meningkatkan bobot biji yang selanjutnya dapat meningkatkan vigor dan ketahanan simpan benih dan menghasilkan fitin yang berperan dalam pembentukan energi yang diperlukan dalam perkecambahan. Menurut Supadma (2007), kalium berperan dalam pengisian biji, metabolisme karbohidrat, dan transportasi asimilat dari daun ke seluruh jaringan tanaman.

Indikator untuk menentukan vigor benih antara lain melalui indikasi fisiologis dan biokimia. Indikasi fisiologis dapat dilakukan dengan uji kecepatan berkecambah, keserempakan berkecambah, dan uji daya berkecambah. Salah satu indikasi biokimia adalah daya hantar listrik cairan rendaman benih. Rusaknya membran sel pada benih mengakibatkan kebocoran gula dan elektrolit sehingga efisiensi metabolisme dan transportasi menurun. Makin tinggi nilai DHL yang diperoleh, maka kebocoran membran semakin besar. Hasil penelitian menunjukkan bahwa benih yang berasal dari pemupukan NPK majemuk tidak berpengaruh pada nilai daya hantar listrik.

Kecepatan perkecambahan, kecambah normal yang tumbuh, panjang hipokotil, dan nilai daya hantar listrik menunjukkan hasil yang tidak berbeda sejalan dengan hasil penelitian Wardhana (2009) yang menyimpulkan bahwa benih yang diberi pupuk NPK majemuk secara bertingkat tidak berbeda untuk daya berkecambah, keserempakan perkecambahan, dan uji daya hantar listrik kedelai.

Hasil penelitian menunjukkan bahwa benih yang berasal dari pemupukan NPK majemuk sampai dosis $300 \mathrm{~kg} \mathrm{ha}^{-1}$ memberikan pengaruh pada vigor benih kedelai Varietas Grobogan berdasarkan variabel panjang akar kecambah, panjang plumula, dan bobot kering kecambah tetapi tidak berpengaruh pada kecepatan perkecambahan, kecambah normal yang tumbuh, nilai DHL, dan panjang hipokotil. Bobot kering kecambah maksimum diperoleh pada dosis pupuk NPK majemuk $178,95 \mathrm{~kg} \mathrm{ha}^{-1}$ yaitu $0,08 \mathrm{~g} / \mathrm{kecambah}$.

\section{KESIMPULAN}

Benih kedelai Varietas Grobogan yang berasal dari pemupukan NPK majemuk sampai dosis $300 \mathrm{~kg}$ $\mathrm{ha}^{-1}$ menghasilkan kecenderungan vigor benih secara kuadratik berdasarkan variabel bobot kering kecambah. 
Pada dosis pupuk NPK majemuk 178,95 $\mathrm{kg} \mathrm{ha}^{-1}$ menghasilkan bobot kering kecambah maksimum yaitu 0,08 g per kecambah.

\section{SANWACANA}

Ucapan terima kasih kepada Ir. Eko Pramono, M.S. atas motivasi dan bimbingannya selama proses penelitian hingga pembuatan skripsi.

\section{DAFTAR PUSTAKA}

AOSA. 1983. Seed Vigor Testing Handbook. Prepared by The Seed Vigor Test Committee of The Association of Official Seed Analys Contribution. No.32.88p

Avintari. 2008. Pengaruh Peningkatan Dosis Pupuk NPK Tambahan Pada Viabilitas Tiga Umur Simpan Benih Buncis (Phasedus vulgaris L.) Skripsi. Fakultas Pertanian Universitas Lampung. $87 \mathrm{hlm}$.

Bewley, D.J. and M. Black. 1986. Seeds Physiology of Development and Germination. Second Printing. Plenum Press. New York. Pages 136139.

Ilyas, S. 2010. Ilmu dan Teknologi Benih. Teori dan Hasil-hasil Penelitian. Institut Pertanian Bogor. Bogor. 95 hal

Lowe, L.B., G.S. Ayers, and S.K. Ries. 1972. Relationships of seed protein and amino acid composition to seedling vigor and yield of wheat. Agro. J. 64:638-642.
Mugnisjah, W.Q., and S. Nakamura. 1984. Vigour of soybean seed production produced from different nitrogen and phosphorus fertilizer application. Seed Sci. Technol. 12:475-482.

Mugnisjah, W.Q., dan A. Setiawan. 2004. Produksi Benih. Bumi Aksara. Jakarta. 129 hlm.

Rusdi. 2008. Pengaruh Pupuk NPK (16:16:16) Susulan Saat Berbunga Pada Produksi Benih Kedelai (Glycine max [L.] Merr.) Varietas Anjasmoro. Skripsi. Fakultas Pertanian Universitas Lampung. $69 \mathrm{hlm}$.

Sadjad, S. 1993. Dari Benih kepada Benih. PT Gramedia Widiasarana Indonesia. Jakarta. 144 hlm

Supadma. 2007. Pengaruh Pemberian Beberapa Dosis Pupuk (N,P,K) dan Jenis Pupuk Alternatif Terhadap Hasil Tanaman Padi (Oryza sativa) dan Kadar N,P,K Inceptisol Selemadea, Tabana. Agritrop. 26(4):168-176.

Sutopo, L. 2002. Teknologi Benih. Raja Grafindo Persada. Jakarta. $247 \mathrm{hlm}$.

Wardhana, A.P. 2009. Pengaruh Dosis Pupuk Nitrogen, Fospor, dan Kalium Pada Produksi Benih Padi Varietas Mira I di Tiga Lokasi Kabupaten Lampung Utara. Skripsi. Fakultas Pertanian Universitas Lampung. $93 \mathrm{hlm}$. 